Abstracta Iranica Abstracta Iranica

Revue bibliographique pour le domaine irano-aryen

Volume 22 | 2001

Comptes rendus des publications de 1999

\title{
«Sur deux noms persans d'instruments de musique ». Studia Iranica, 28, 2 (1999), pp. 297-9.
}

\section{Rédaction}

\section{(2) OpenEdition}

1 Journals

\section{Édition électronique}

URL : http://journals.openedition.org/abstractairanica/37371

DOI : 10.4000/abstractairanica.37371

ISSN : 1961-960X

Éditeur :

CNRS (UMR 7528 Mondes iraniens et indiens), Éditions de l'IFRI

\section{Édition imprimée}

Date de publication : 15 mai 2001

ISSN : 0240-8910

Référence électronique

Rédaction, « «Sur deux noms persans d'instruments de musique ». Studia Iranica, 28, 2 (1999),

pp. 297-9. », Abstracta Iranica [En ligne], Volume 22 | 2001, document 659, mis en ligne le 17 février

2010, consulté le 13 octobre 2020. URL : http://journals.openedition.org/abstractairanica/37371 ;

DOI : https://doi.org/10.4000/abstractairanica.37371

Ce document a été généré automatiquement le 13 octobre 2020.

Tous droits réservés 
«Sur deux noms persans d'instruments de musique ». Studia Iranica, 28, 2 (1999), pp. 297-9.

Rédaction

L'auteur avait déjà identifié le nom avestique de la trompette («Cor de Yima et trompette d'Israfîl, de la cosmogonie mazdéenne à l'eschatologie musulmane», Académie des Inscriptions et Belles Lettres, 1979, pp. 539-549). Il établit l'évolution du grec psalterion en santûr et de lûd en rûd, le luth, et non la harpe.

INDEX

Thèmes : 17.1.Musique

\section{AUTEURS}

RÉDACTION

Directeur de la revue et secrétariats (Paris et Téhéran) 